\title{
American Factors And The Difficulties of Folks Exchanges between China And Japan
}

\author{
Yang Shuo, Wei Xiaodong* \\ BEIHUA UNIVERSITY, COLLEGE OF MARXISM, JILIN CITY JILIN PROVINCE, CHINA \\ ${ }^{*}$ Corresponding author WEI XIAODONG
}

Keywords: American factors, Folks exchanges between China and Japan.

\begin{abstract}
From the view that dealing with Sino-Japan relationship well is beneficial to Asian and world peace and on hard times of developing SinoJapanese political relatons, The New China gover nment makes one folk diplomacy that folk diplomacy comes first and then promotes the official dipl omacy. through carrying out this diplomatic policy progressively, it is helpful to blaze a way and cre ate conditions for acheveing the normalization ofSinoJapanese diplomatic relations. However, this $\mathrm{p}$ rogress is hard to be kept on for American intervene. The American government cuts off the SinoJapanese trade path and prevent Folks trade exchanges between Sino-Japan government. Meanwhile, The Japanese government also carries out the Pro-American government's diplomatic policy.
\end{abstract}

\section{The American government cuts off The Sino-Japanese trade path}

After korean war, The American Government begins the strategies completely to curb China. To be still able to control Sino-Japanese trade strictly after San Francisco treaty going into effect, The United States National Security Council first has discussions on the prospect of trading with Japan and socialist countries, especially the Soviet Union and China in Otc. 1951. On 28.Mar.1952 before San Francisco tread going into effect, The American Government sent a note to the Japanese Government whose nearly all goods export control rights are deprived by American Government, and ordered The Japanese Government to continue carrying out the policy that prohibits all trade transportation to China at least before korean war. In 30.May, The Japanese Government replied a note to American Government that expresses their wishes to join the coordinating committee for multilateral export controls. The Japanese replied note aims to reduce its China trade restriction level as equal as other western countries' levels. However, The American Government actually intended to set up an independent organization with its allied countries cooperatively, named Far Easrern Commission, which is especially directed against the Asian trade with more serious control. But this proposal is not accepted by western countries like Britain and France. To balance The allied countries benefits, from the end of July. to August, 1952, five countries, including America, Britain, France, Canada, Japan had talks in Washington. Two results came out after he talks. The first one is that within coordinating committee for multilateral export controls, one additional autonomous committee including Japan is directed against China, whose name is export control committee to China or China committee. this committee is to strengthen the blockade and prohibited transportation to China. The second result is that Japanese Government gets permission to join coordinating committee, but American Government raise one requirement that the Japanese Government should make a promise that The Japanese Government should keep its present level approximately to China trade prohibited transportation. Even if this requirement is against Japanese will to join the coordinating committee, The Japanese Government has to accept it under the American strong attitude. In 5,Sep, the American Government forced the Japanese Government to sign a guarantee paper named 'Japanese-American understanding letter on export control of communist China'. according to this understanding letter, The Japanese Government should not only prohibit transportation of goods within the international prohibited goods lists, But also prohibit shipments of the goods beyond the international prohibited goods lists but in American 
prohibited goods list. Meanwhile, this understanding letter requires the Japanese Government to prohibit transportation on other materials that are permitted by both sides of American and Japanese Governments. in this case, the American Government ties 'independent position“ Japan to his curbing China policy firmly by joining Japan in coordinating committee finally and forcing Japan to sign the guarantee letter. it is undoubtedly a curbing force to Japan which follows America tightly in dealing with diplomatic relations after war.

\section{The difficult development between Sino-Japanese folks trade}

The blockade and prohibited transportation policy carried out by American and Japanese Governments makes nearly all trades between Sino-Japan cut off. In such circumstance, lots of enterprises related with Sino-Japanese trade are in difficult situation. Both Japanese people and businessmen are unsatisfied about this situation and strongly desirable to ask recovery of SinoJapanese trade and business. Meanwhile, to carry forward the construction of China, the Chinese Government and people are also extremely willing to have a friendly trade with Japan.

On 14.Dec.1951, President of China Bank, Nan Hanchen, as one sponsor of Moscow international economic conference, wrote letters to invite Japanese political and business celebrities actively to join this conference. The noted representatives from Japanese different areas like contain shengzang and shiqiaozhanshan give positive replies to this invitation. They set up a international economics conference for discussion and decision and finally They determined to assign a delegation forward the conference. Unfortunately, The delegation fails to apply their visa. Because the Japanese embassy refuses them for immature time. But the Japanese Government action can not stop the determination of parliament members(GaoLiangfu.FanZuji and Gongyaoxizhu) to participate in this conference. They take round about manner and finally gather in Moscow in 29.Apr. 1952. and Chinese delegation also gives invitation to these three Japanese parliament members to visit China. and They arrive in China in 15.May. They become the first Japanese friendly people visiting China after new China built. After many talks with Chinese related authorities, like China international trade promote committee chairman Nan Hanchen, The first trade negotiation is signed on behalf of person in charge or representative of their own trade group in 1st, June by both sides. This negotiation creates condition for raising and carrying out the policy named 'folks to promote officials' made by Chinese Government. Another three trade negotiations are signed on 29.Otc.1953 in Beijing von 4.May.1955, inTokyo and on 5. Mar.1958, in Beijing respectively in order by Sino-Japanese folks.

Seeing from the carryout situation of negotiation or agreement in overall, only the fourth Sino Japanese trade negotiation can not be carried out for Japanese Government carrying out positively anti-China policy. even the specified trade volume of other three trade negotiation or agreement can not be completed after time-extended carryout, But the trade amount between China and Japan keeps increasing continuously. and from the third trade negotiation, both sides can arrange goods exhibition in each other's country individually. In overall, the folks trade between China and Japan during 1950s are in the process of hard developing and slowly moving forward for AmericanJapanese blockade and prohibited transportation to China.

\section{American-Japanese Governments obstruct the folks trade evolvement between Sino-Japan}

To Japan, the San Francisco treaty coming into effect marks the beginning of Japanese Government returning to international society as an independent country. But due to The drawn up and carryout the security treaty between Japan and America, the Japanese Government is perfectly justifiable again to attach to the American Government's 'half-occupied status. The operation of alliance organization in form of 'America leads and Japan follows' must make the Japanese Government choose to follow the American will on the policies to China.

The time that the first folks trade negotiation is signed by Sino-Japanese Governments is just about the best crazy moment that the American Government forces the Japanese Government to carry out the blockade and prohibited transportation to China. SO the first folks trade negotiation 
carryout has to face many obstacles from American and Japanese Governments. First, the American Government strongly disagree to carry out of this negotiation. in the view of American Government, the prohibited transportation policy not only has economic implications, but also has more important psychological and political influence. The Japanese Government doesn't dare to implement the blockade and prohibited transportation policies more flexibly for the attitude of American Government. According to the trade negotiation, Mr. Yingjingyingxiong, President of Japanese company, signed one 38,000 pounds contract with one Chinese import and export company in Beijing on 28.Nov.1952. This is the first contract that follows the Sino-Japanese trade negotiation content. After the contract signed, the Japanese bank refused to provide the credit certificate which caused the first contract failed to be carried. as to the implementation result of the first Sino Japanese trade negotiation. even prolonging the carryout twice within 16 months( from 1st.Jun. 1952, to 29.Oct.1953),

After korean war is over, the American Government continuously strengthen the curbing situation to Chinese Government. On 21.Otc.1953, the American Government sent a memorandum to Japanese Government which expresses its political intention to continuously implement the strict restriction to Sino Japanese trade. But to the Japanese Government that is facing to the difficulties of economic development, there are growing calls to expand the trade to China day by day. The promoting Japan-Sino trade resolution get passed by house and senate of Japanese congress on 29 and 30.July.1953, which requests to reduce the prohibited transportation restriction to China in order to implement and expand trade between Japan and China. The American Government feels dissatisfied with the second Sino Japanese trade negotiation that is signed in Beijing on 29.Oct.1953. Just for this matter, the American and Japanese Governments jointly delivered a statement on purpose to emphasize that the relax for goods list on China communist trade aspect should be processed by diplomatic institution. Meanwhile, the mistaken policy carried out by Jitian Government in Sino Japanese trade, which makes politics and economics separated is another reason why the implementation for folks trade negotiation is not perfect and successful. because of this policy, the Japanese Government doesn't give any guarantee for Sino Japanese folks trade, which must take many obstacles to the folks trade between China and Japan. On 8, Mar.1957, the United States National Security Council made NSC5704/No.1 document (《American economics defense policies $\rangle)$, and again stressed on the point that the trade control and restriction to communist China should be more strict than another Soviet countries. According to this base, the Ann's Government that firmly carries out pro-America and anti-China policy crazily destroyed the fourth Sino Japanese folks trade negotiation, which finally caused most serious setback to Sino Japanese folks trade during his term of office all above can deeply show that if American and Japanese Governments don't give up their hostility and curbing policy to China. or if the normalized relation between China and Japan cannot be achieved, the trade business and friendly goes and comes are impossible to achieve any expansion or development

\section{Acknowledgement}

The essay is funded by Jilin province, education department scientific research program (2016. No.35) and is also one phased research achievement of studying 《The reason on American long period intervene the Sino Japanese relation after New China built and its history implication》

\section{References}

[1]Cui Pi: American cold war strategy and Paris coordinating committee, China committee, Chang Chun, Northeast Normal University Press(2000).

[2]The First Secretary of Embassy in France to the Department of State, April 24, 1954, FRUS ,Indochina, Vol. XIII, 1 952-1954, pp.1328-1334.

[3] Lin LianDe:Contemporary Sino-Japanese Trade Relation History, China International Business 
and Economics Press(1990),p.18.

[4] Gongzeqingcilang, Japan-American relation after war, translated by workers from Shanghai NO.3 radio factory in a collective effort. Shanghai people press(1977), p.16.

[5] National Security Council Paper, Statement of U.S. Economic Defense Policy, Washington, March 8, 1957, FRUS, Foreign Aid and Economic Defense Policy, Vol. X, 1955-1957, pp. 428-431. 